\title{
Obituaris
}

\author{
Carlota Solé
}

Universitat Autònoma de Barcelona. Departament de Sociologia

08193 Bellaterra (Barcelona). Spain

\section{James Coleman}

James Coleman morí el dia 25 de març de 1995 a Chicago a l'edat de seixanta-vuit anys. Catedrattic de la Universitat de Chicago, Coleman era un dels sociòlegs contemporanis més famosos $i$, sobretot, més actuals. Va crear la teoria i la metodologia d'una nova ciència social orientada a tractar els grans problemes de la política pública. És per això que avui es coneix i reconeix internacionalment la contribució de Coleman a l'anàlisi del canvi social, de l'acció col-lectiva i de l'elecció racional. Coleman es Ilicencia en enginyeria química el 1949 a la Universitat de Purdue i es doctora en sociologia a la Universitat de Colúmbia. Del 1956 al 1959 és docent a la Universitat de Chicago i poc després exerceix com a catedràtic a la Universitat de John Hopkins on crea el Departament de Relacions Socials, del qual és director fins al 1973. Aquell any torna a Chicago on investiga i dóna classes fins al 1995. Autor de trenta liibres i de més de tres-cents articles i capítols de llibres i fundador el 1989 de la revista Rationality and Society, Coleman és un dels sociòlegs contemporanis que més ha contribuitt a ampliar els horitzons de la teoria sociològica i a forjar una aproximació interdisciplinar als fenomens socials.

El punt de partida de Coleman és la sociologia de l'educació i les polítiques públiques. L'any 1966 es publicà l'Informe Coleman o Coleman Report, centrat en un estudi sobre la igualtat d'oportunitats d'educació (Equality of Educational Opportunity). A partir de la utilització d'un gran nombre de dades sobre les escoles i l'escolarització, Coleman arriba a la conclusió que els nens de raça negra i classe baixa es beneficien acadèmicament del fet de trobar-se escolaritzats en escoles integrades. Estudis posteriors tracten de comparar l'eficàcia relativa de les escoles primàries públiques i privades. L'any 1982 Coleman escriu: High School Achievement: Public, Catholic and Private High Schools Compared i l'any 1987 és coautor de Public and Private High Schools: The impact of Communities (W. Harms, 1995). 
Paral-lelament revisa $i$ analitza les dades provinents de diverses ciutats que havien implantat programes correctius (equivalents a l'educació compensatòria) per tal d'integrar estudiants blancs i negres en una mateixa escola. La conclusió de Coleman a aquesta recerca fou controvertida i contrària a la seva pròpia visió anterior: els blancs abandonen massivament les escoles públiques en les quais s'han posat en pràctica programes d'educació compensatòria.

Aquesta conclusió és aplicable a la formació de guetos urbans paral.lela a l'arribada d'immigració estrangeta. Malgrat les polítiques integradores que duguin a terme els departaments de Benestar Social dels governs centrals o regionals o els serveis socials dels ajuntaments envers la immigració de caràcter econdmic de persones procedents de l'anomenat Tercer Món, no es pot evitar que, un cop se supera la proporció d'un terç o un quaranta per cent aproximadament de població immigrada resident en un barri, els qui hi han viscut tota la vida comencin a marxar cap a d'altres barris on residir-hi. No existeixen suficients incentius addicionals perquè, atesa la circumstància de la immigració estrangera, els autòctons persisteixin a viure en el mateix barri de sempre.

Aquesta conclusió duu Coleman a profunditzar en els fonaments de la conducta humana. Durant dues dècades adapta la teoria de l'elecció racional, d'arrel i d'aplicació estesa en economia, a l'explicació de situacions socials en les quals el comportament individual s'ha d'entendre immers i influït o afectat per les institucions o l'estructura socials. Fruit de la seva indagació i recerca és una obra, ja clàssica, publicada l'any 1990: Foundations of Social Theory. En aquesta obra Coleman mostra com les decisions i eleccions individuals es troben condicionades per les normes socials, la pressió social o dels semblants, el desig d'emular els líders d'un grup, $\mathrm{i}$ aitres influències grupals.

La creença de Coleman en l'elecció racional no l'inhibeix a l'hora d'adoptar un compromís moral com a sociòleg. Per a ell la ciència social no es pot justificar simplement com un exercici intel.lectual, sinb que ha de servir per a mostrar als polítics i gestors de la cosa pública com han de dissenyar la legislació que permeti millorar el benestar social. El 1980 dirigeix un equip d'investigació per a realitzar un survey de setanta-cinc mil persones entrevistades, de cap a cap dels Estats Units, per tal de fer un seguiment i analitzar els efectes de l'educació en la vida i carrera dels qui l'any 1980 eren estudiants d'ensenyament secundari (de segon o tercer curs: sophomores i seniors). Altres compromisos els pren en relació amb la professió de sociòleg. Era membre de la National Academy of Sciences, l'Amercian Philosophical Society, l'American Academy of Arts and Sciences, la National Academy of Education y la Royal Swedish Academy of Sciences. Malgrat el rebuig i l'amenaça d'expulsió que rep de I'Associació Americana de Sociologia, l'any 1991 n'és nomenat president pel suport massiu com a canditat extern. Un any més tard l'ASA li concedeix un premi per l'obra Fonaments de teoria social. Aquest és només un exemple dels molts premis i reconeixements que rebé durant els últims quinze anys de la seva vida.

Juntament amb el seu col-lega i amic Gary Becker, James Coleman funda l'any 1980 a la Universitat de Chicago un seminari interdisciplinar sobre l'elec- 
ció racional en les ciències socials. El seminari ha estat un fòrum de discussions cientffiques rigoroses sobre la força i la feblesa de l'enfocament de l'elecció racional a l'hora d'interpretar el comportament social, polític i econòmic. Aquests dos autors es complementen en l'anàlisi del comportament humà $i$ les seves conseqüències en la formació d'institucions (com la família, el matrimoni, el divorci, l'empresa, el sistema de partits polítics) o fenòmens socials (com la discriminació o la criminalitat) des d'un enfocament alternatiu al tradicional, i nou en la sociologia contemporània (C. Solé, 1993).

\section{Bibliografia}

HARMS, William. 1995. "James Coleman" obituari. Universiy New Office. Chicago: University of Chicago.

Sol.E, Carlota. 1993. "J. Coleman y G. Becker: el enfoque económico en sociología". Revista Intemacional de Sociologia, núm. 6, setembre-desembre. Cordova: IESACSIC. 